\title{
Ideology and Cultural manipulations in Translation \\ (A Hermeneutic Approach)
}

\section{Hesham sayed Abdelnasser}

\begin{abstract}
:
The reading of an original text and its given translation points out some semantic differences. A translation of a certain text which is produced by a specific translator differs from translations by other translators, as it is a human product. The manipulation school refers to ways of adjusting or modifying a source text, consciously or unconsciously, by the translator so as to make it acceptable and corresponding to his own ideology.

This paper investigates essential questions regarding cultural manipulation and ideology from a translation studies perspective. The paper discusses how much the translation can be manipulated by translator's ideology. The main interest is in how ideology is conveyed and presented textually in translation, causing cultural manipulation. The study adopts Hermeneutic theory to understand, analyze, and compare the source text with the target text.

The paper presents a comparative analysis of the source text of Shakespearian play "Measure for Measure" and the given Arabic translation "Dakah bi Dakah" by Dr. M. Enany. Though Shakespeare introduces a polemic to his readers to give them the chance to evaluate and decide whether the hero is guilty or not, Enany consciously manipulates the source text, damages the polemic of the story and converts the hero into an innocent person who faces injustice to raise his readers' sympathy. Then the paper presents another Arabic translation by Ibrahim Zaki Khurshid in which the translator manages to keep original meaning and the introduced polemic.
\end{abstract}


The paper reveals that manipulation is conducted by Enany due to an ideological reason, namely Religion. Accordingly, translators should neutralize themselves and keep the introduced ideology of the original texts.

Key words: "Manipulation", "Ideology", "Hermeneutics", "cultural manipulation"

The paper counters some basic questions such as: What is meant by ideology? What is the relation between ideology and translation? What is cultural Manipulation? What is Hermeneutics? What is the relevance of Hermeneutics to the study of translation, Ideology and cultural Manipulation? The answers to the previous questions are forming the study in hand;

\section{- What is Ideology?}

The term 'ideology' is generally considered to be a set of conscious and unconscious ideas that constitute one's goals, expectations, and actions. An ideology is a comprehensive vision, a way of looking at things (Hershey, 2017).

'Ideology' has been always accompanied by its political connotation as it is evident in its dictionary definition as a 'manner of thinking, ideas, characteristic of a person, group, etc, esp. as forming the basis of an economic or political system' (Oxford Advanced Dictionary of Current English, 1984).

Under the influence of Marx who defines ideology as an action without knowledge (false consciousness), ideology is sometimes defined in its negative political sense as 'a system of wrong, false, distorted or otherwise misguided beliefs'. (Calzada-Pérez, 2003: 3)

\section{- Manipulation}

According to the theory of Manipulation, translation implies a degree of manipulation of the ST for a certain purpose, because the translation process brings the TT into line with a particular model which should secure social acceptance in the target culture. 
Explicitly, the theory is in sharp contrast with linguistic theories of translation because from the start it approaches translation not as science, but as an art which permits manipulation rather than equivalence, thus it is concerned with literary, not technical translation. Accordingly, the translation process is deemed a rewriting process and the translator is a re-writer who can alter or manipulate the ST in such a way as to be acceptable in the target language and culture.

This theory is adopted by a group of scholars associated with a particular approach to the translation of literature, and to what is known as 'Manipulation School' and also as the 'Descriptive, Empirical or Systemic School. (Hermans, 1995: 217 in Shuttleworth: 101-102)

\section{- The Manipulation School}

The name Manipulation School comes from an anthology of essays published in 1985, and edited by Theo Hermans entitled 'The Manipulation of Literature: Studies in Literary Translation'. In the introduction, Hermans states, "From the point of view of the target literature, all translation implies a degree of manipulation of the source text for a certain purpose". (Hermans, 1985: 4)

\section{- "Manipulation" in Translation Studies:}

The term "translation studies" was first put forward by James Holmes. In his paper "The Name and Nature of Translation Studies", Holmes made a comparison amo00ng "translation studies", "science translation" and "translation theories", suggesting that translation studies seem to be the most appropriate. Holmes conceived of the approach as an empirical practice, one which looks at the actually translated texts as they appear in a given culture (Gentzler, 2004: 93). Later on the term "translation studies" was frequently used by Lefevere and Bassnett. The 1970s witnessed the "cultural turn" in translation studies in western countries. Polysystem theory, descriptive translation studies, and manipulation school were the most influential at that time (Hermans, 2004: 13). The term "manipulation" is 
almost associated with "culture" and "translation". (International Journal of Humanities and Social Science, 2013)

\section{- Hermeneutics}

Hermeneutics is a term that is derived from the word "hermetic" which means "magic" and "ambiguity. Others argue that it is derived from the old Greek translation of the Egyptian God "Thoth" - "Hermes" the mythical writer of the mysterious and magic texts. The word "Hermenus" is an Ancient Greek word for interpreterltranslator and it is directly related to God Hermes .The verb "Hermeneuo" means;

- interpret foreign tongues

- translate

- explain, expound

- put into words, express

The term was introduced c.360 BC by Aristotle in his text (Peri Hermeneias, "On Interpretation"). It is often suggested that the Greek word root is etymologically related to the name of the Greek mythological deity Hermes, but cognate to a corrupted composite borrowing from Hebrew Har [ha]Emet (Emes) referring to the Biblical Mount Sinai where Moses interpreted the Jewish Law (known as haEmes ("the Truth") to the people. (Yourdictionary, 2015)

Hermeneutics is defined as "The branch of knowledge that deals with interpretation, especially of the Bible or literary texts. (Oxforddictionaries, 2017). The term "Hermeneutics" was used to refer to "The New Testament" interpretation.

Hermeneutics briefly can be defined as the science and methodology of interpreting texts. The process of discovering the correct meaning of a text is the core of hermeneutics. 


\section{- The relevance of Hermeneutics to the study of translation, Ideology and cultural Manipulation.}

Upon the nature of the relation between Hermeneutics and Translation James M. Robinson, in his article, "Theology as Translation" argues that: "Not only do translation and interpretation belong together; they in turn share with language a basic scope. For language itself is the bringing of expression, the exposition, of an understanding. Language is already the bringing of the hermeneutical process. Thus, one catches sight of the basic interrelatedness of the problem of the word of God and that of theological hermeneutic." (James Robinson, 2007:518)

James Robinson argues that translation and interpretation are closely related to each other as they are sharing the same field, namely, the language. Language is the first hermeneutic step as it is the expression of a certain understanding. The process of translation can be described within the frame of interpretation which could accordingly be described as hermeneutic, and accordingly, the task of translation is not met simply by replacing the vocabulary and grammar of one language with that of another. The translation must go much further if it is to complete its task.

Again the relation between "Hermeneutics" and translation is that there is no translation without understanding and interpreting texts, which is the initial step of any kind of translation including literary translation. Inappropriate understanding inevitably results in inadequate interpretation.

Throughout the development of hermeneutics as a theory of understanding interested in a comprehensive actualization of the author's motives and the text in its social, cultural and historical background, and by realizing the Hermeneutic circle which refers to the study of semantics (including the study of both; context of situation and semantic field) the relevance between Hermeneutics and translator's ideology becomes fundamental and reasonable grounds for the process of manipulation. 


\section{- The Hermeneutic Methodology:}

To analyze the text hermeneutically, the researcher takes into consideration the following three elements, namely, the author, the text and the reader. The author element is analyzed on the basis of Schleiermacher's views. The text element is analyzed semantically. The semantic analysis is based on two elements the first of which is the context of situation which is contingent upon Malinowski's views (1884-1942), and Firthian context of situation (1957). The second one is that the semantic field which is based on Nida's theory (1964:50). The last element i.e. the reader is studied according to the reception theory of Hans Robert Jauss in his book 'Toward an Aesthetic of Reception (Theory and History of Literature)', (1982).

The three elements (components) of analysis will be approached according to the following frame of work.

\section{The author:}

To analyze hermeneutically, a thorough study of the author's life experience, historical and social background (resulting in understanding author's ideology) is of paramount necessity for any translator to ensure interpretation of the author's meaning. Schleiermacher comments upon the element of the author in his words as follows: One must already know a person in order to understand what he says, and yet one is supposed to get to know him by what he says.( Peter Szondi, 1995: 119)

\section{The text:}

In analyzing the text hermeneutically, two aspects should be taken into account:

a) Semantic Analysis, Semantics is the technical term used to refer to the study of meaning (F.R.Palmer, 1996:1). It studies the relation between words and the objects they represent and the situation in which they are used. The current study will approach two points semantically. 
1- Context of situation. The term context of situation is associated with two scholars. The first is an anthropologist, Malinowski, who claims that the utterance can make sense only if it was seen in the context in which it occurred. He mentions:

Language is a "mode of action" not a "countersign of thought" (Ibid, P.1).

His remarks about language were useful in terms of what he viewed language in that it is not simply a matter of stating information, yet he did not touch on the way in which context could be handled in a systematic way to provide a statement of meaning.

The second scholar whose name is associated with context of situation is John Rupert Firth commonly known as J. R. Firth. He views context of situation as part of the linguist's apparatus in the same way as are the grammatical categories that he uses. He suggested the following categories:

A.The relevant features of the participants: persons, personalities

(i)The verbal action of the participants.

(ii)The non-verbal action of the participants.

B.The relevant objects.

C.The effects of the verbal action. (Ibid, P.53)

In this way context of situation can be grouped and classified; this is essential if it is to be part of the analysis of the language.

2-Semantic field: In the discussion of the semantic field, we shall be concerned with paradigmatic relations. The most famous example for field theory is that of Trier(1934) who compared the field of the intellectual aspect of German of around 1200 with that of around 1300. His example compared a single language at two different periods. Two languages can also be compared to see the way in which they divide a particular field.

Nida in his book 'The Theory and Practice of Translation' (1964:50), on the other hand, discusses, in term of class, words in the Mexican language for noise: 
there are six "noise" words referring to, children yelling, people talking loudly, people talking angrily, people arguing, increasing noise, funeral noise.

In all these examples we have a list of words referring to items of a particular class dividing up a semantic field or a field of meaning.

In some cases the distinction between the terms in the field is clear; in other cases, the distinctions are far more blurred. The terms in the field are "unordered" (Ibid, P.70). Actually, in all cases, all items in a certain semantic field seem to have the same paradigmatic relation.

\section{The reader:}

When approaching a given text, readers may have different interpretations. A basic acceptance of the meaning of a given text tends to occur when a group of readers have a shared cultural background and interpret the text in similar ways. It is likely that the less shared heritage a reader has with the artist, the less he/she will be able to recognize the artist's intended meaning, and it follows that if two readers have vastly different cultural and personal experiences, their reading of a text will vary greatly, accordingly, readers' various reception approaches will lead us to what is known as the reception theory.

The significance of the element of the reader has escalated to the extent at which Schleiermacher noted that in order - for a given researcher - to reach an impeccable comprehension of a given text, he/she should wear the hat of a reader to understand the atmosphere, allusions and the special field of images of a given text. "One must try to become the immediate reader of a text in order to understand its illusions, its atmosphere, and its special field of image." (Quoted in Peter Szondi, 1995:119)

The Reader element has been approached by Gadamer, as such, there is a vast gap between the meaning of the written text in the past and in the present, Gadamer's view is tackled by Dr. Mohammed Shible Al-Komy in his book AlMazaheb Al-Nakdya Al-Hadetha: 


$$
\text { "دلالة النص تتغير تغيراً كبيراً من قارىء لآخر تبعاً لزمن القارىء و ظروفه الشخصية و }
$$

(Mohammed Shible Al-Komy, 2004:312) the connotational meaning of the text is very changeable from a reader to another according to his period, and his personal and social circumstances.

He illustrates that the social backgrounds of a reader and his mentality affect his understanding of the text, thus this understanding can be different from one reader to another.

\section{- Reception theory:}

It is a version of reader response literary theory that emphasizes the reader's reception of a literary text. In literary studies, it originated from the work of HansRobert Jauss in the late 1960s. It was at its most influential period during the $1970 \mathrm{~s}$ and early 1980s in Germany and USA amongst some notable works in Western Europe.

This approach to textual analysis focuses on the scope for "negotiation" and "opposition" on the part of the audience. This means that a "text"— be it a book, movie, or other creative work-is not simply and passively accepted by the audience, but that the reader / viewer interprets the meanings of the text based on their individual cultural background and life experiences. In essence, the meaning of a text is not inherent within the text itself but is created within the relationship between the text and the reader. (Miller, 2012)

Reception theory is defined as the approach to literature that concerns itself first and foremost with one or more readers' actualization of the text.

\section{-How can ideology be conveyed in translation causing cultural manipulation?}

Measure for Measure is a poetic play written by Shakespeare in which he tackles a crucial social religious issue at that time. The play discusses the consummation of marriage (to make a marital union complete by sexual 
intercourses) before the final approval of the church, where this approval is the last of the four steps of marriage.

It is not a one-shot step by which a single person changes into a married in a day. The first step is called (courting) step through which the bridegroom tries to get the acceptance as an expected life partner or as a possible husband.

The following step which is the (formal private promise), that leads to the third step which is the (betrothal), that takes place in public in a (hand-fasting) party. In this party, the couple exchanges the marriage swears, in presence of the witnesses.

In most cases, the couple considers that actually they have been married, and then they can begin their sexual life. While the church doesn't consider so, unless by reading the (banns) and by the attending of newly-weds in the church on Sunday for three sequent weeks adding to the dowry that should be paid first.

The complexity of the previous churchly marriage steps led to the neglecting of the church in England to those who had begun their sexual life at the early steps of marriage.

Briefly, the person should accept to be considered not single and not married at the same time, or to be considered single and married at the same time.

The story tells us that the governor Duck Vincentio leaves and appoints his deputy Angelo, who finds that the adultery law is not applied "Execution is for the man or the woman who commits adultery, or (marriage consummation before the churchly ceremony).

Claudio and Julietta passed all the marriage steps except the last one (reading the ceremony and the two families' negotiation about the dowry). Claudio has consummated the marriage and Julietta gets pregnant. Angelo insists that the death penalty must be implemented to Claudio.

This is a polemic, which need not to be resolved initially. The polemic should continue to play a part in the reaction of the audience or the receptor. Some readers will accept that Claudio had married to Julietta, others will not accept Claudio's marriage before the required churchly ceremony (banns). 
Dr. Enany in his translation "Dakah be Dakah"(2013) doesn't introduce this polemic. He manipulates the original text, consciously and considers the relation between Claudio and Julietta, as a completed valid marriage. He managed to manipulate the issue itself to gain out his readers' sympathy.

He used some well-accepted Arabic and Islamic words and expressions in his translation. For example, in the following quotation - Act I- seen one (Measure for Measure, 2004: 15) - Claudio speaks to his friend Lucio and describes his situation.

\section{CLAUDIO}

Thus stands it with me: upon a true contract

I got possession of Julietta's bed:

You know the lady; she is fast my wife,

Save that we do the denunciation lack

Of outward order: this we came not to,

Only for propagation of a dower

Remaining in the coffer of her friends,

From whom we thought it meet hide our love

\section{a- Dr.Enany translates these words into;}

$$
\begin{aligned}
& \text { كلوديو: هذا حالي : بصحيح العقد تزوجت فتاني جوليتا } \\
& \text { و بنيت بها, و هي المعروفة للك } \\
& \text { و بعهد زو اج موثوق به .. و امام شهود } \\
& \text { لكنا أحجمنا عن اشهار العقد كما تقضي الأعراف }
\end{aligned}
$$

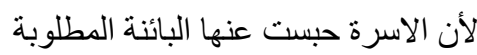

$$
\begin{aligned}
& \text { ولذللك قلنا يستحسن إخفاء الحب عن الناس }
\end{aligned}
$$

The translator uses " زواج موثوق "," بنيت بها ", and " امام شهود " which reflect the legal religious acceptance of this marriage in the Arabic culture so that the reader will wonder 'where is the crime ?', and conclude to that the hero is not guilty. There is no polemic introduced. The original text is culturally manipulated. 


\section{b- Ibrahim Zaki Khurshid "Dakah Bedakah"}

Khurshid was a writer and a critic. He belongs to the first generation of the Faculty of Arts at Cairo University. He is one of the three persons who devoted themselves to translating the British «Islamic Encyclopedia» into English and French in the fifties of the last century.

He wrote comments on the materials of this encyclopedia and corrected some errors of the orientalists. During the last period of his life, he wrote short articles in Al-Ahram literary supplement, in which he described the cultural life.

"الترجمة : He collaborated with other writers in writing many books, including " ثقافة وكتاب " Culture and a Book. He has

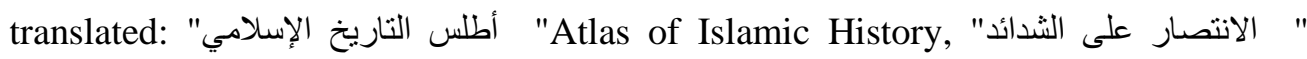
Triumph over Difficulties, and " The (British)Islamic Encyclopedia. (alencyclopedia, 2000)

The previous details about the translator are found on the sites: "alencyclopedia.com" and "faharis.com".

The Arabic translation:

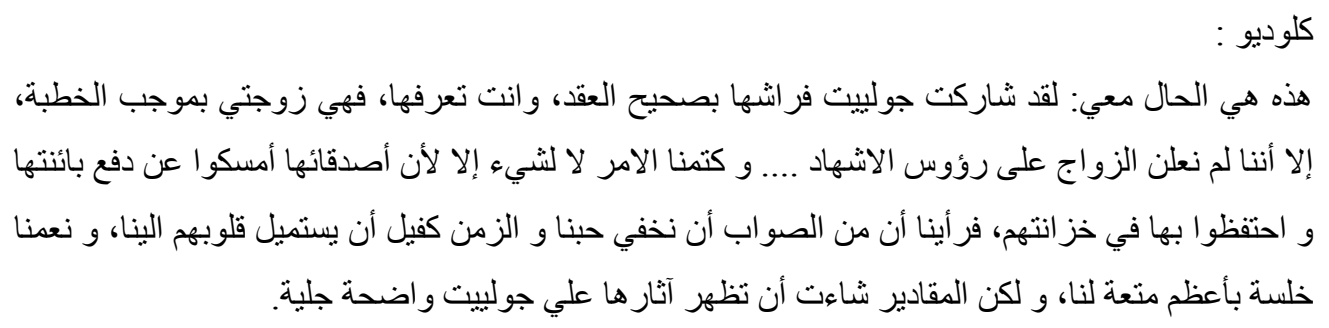

(Ibrahim Zaki Khurshid, 1980:28 ) 
By Comparing the Hermeneutic understanding of the ST to and with that of the Arabic translation, the study can find out to which extent the translator keeps the introduced polemic.

$$
\text { "شاركت جولييت فر اشها " }
$$

" She is my wife by courtship, but we did not announce the consummation."

" نعمنا خلسة "

"We enjoyed stealthily"

By the reading of Khurshid's translation, it is notable that he uses شاركت "جولييت فر اثشها This expression neutrally conveys the original meaning of the ST and does not imply any justifications for the situation of Claudio and does not inspire a certain conviction. Sharing bed can be considered either legitimate or illegitimate "فهي زوجني بموجب الخطبة، الا اننا لم "It transfers the original sense of swinging between Claudio's certain feeling of innocence and his confession of committing a violation of the laws of the church, by not declaring the consummation. Indeed, the sentence "نعمنا خلسةة tends to confirm Claudio's confession of committing a sin though he has good reasons or justifications.

Thus the translator gives the reader the chance to assess the issue from his own perspective and culture to determine either to sympathize with or to condemn Claudio. 


\section{Conclusion:}

Having investigated 'Ideology as a set of conscious and unconscious ideas that constitute one's expectations, actions, and decisions', 'Manipulation, its cultural reasons and ideological motives' and 'Hermeneutics as a theory of understanding', it has been concluded that Hermeneutics is a tightly related approach to the topic of Manipulation and it is one of the finest approaches through which a text can be understood comprehensively considering the author's ideology. Again Hermeneutics can help recognizing the reasons and motives of a certain manipulation in a translation. Accordingly, it has been recommended by the study's findings that translators should analyze the source texts hermeneutically according to the adopted frame work of analysis in this study in order to accomplish an adequate translation, and to avoid unconscious manipulations.

Though Shakespeare introduces in his "Measure for Measure" a polemic to his readers to give them the chance to evaluate and decide whether the hero is guilty or not, Enany consciously manipulates the source text, damages the polemic and converts the hero into an innocent person who faces injustice to raise his readers' sympathy.

That manipulation conducted due to an ideological reason, namely Religion. Enany is convinced as a Muslim that after the (betrothal), which takes place in public in a (hand-fasting) party in which the couple exchanges the marriage swears, in presence of the witnesses, the consummation of marriage (to make a marital union complete by sexual intercourses) is not a sin. He applied the Islamic rules to Shakespearian polemic. On the other hand, Khurshid introduces a good example for transferring the original message of the Author to the Arab readers. Accordingly, it has been recommended by the study's findings that translators should neutralize themselves and keep the introduced ideology of the original texts. That also would help to transfer the foreign cultures to their target readers. 


\section{References}

إبر اهيم- / Alencyclopedia. (2000), n.d. Web. 3 December 2016 http://alencyclopedia.com/ > >

Al-Komy, Mohammed Shible (2004), 'Al-Mazaheb Al-Nakdya Al-Haditha, Cairo; AlHayah Al-Amalelketab

Aiwei Shi, (2014) 'Hermeneutics and Translation Theory', 4 September <www.translationdirectory.com/article115.htm>

Calzada-Perez, M, (2003). (Ed.) 'Apropos of ideology' Manchester: St. Jerome.

Daniel Colvin. (1999), "Introduction to Measure for Measure". n.d. Web. 7 January 2016 <http://college.holycross.edu/projects/isp /measure/ essays/1_1_Introduction.html>

Gadamer Hans-Georg, (1989) 'Truth and Method', $2^{\text {nd }}$ rev.end., tr.Joe 1 Weinsheimer and Donald G. Marshall(New York),pp.218ff.

Gentzeler, E. (1993) 'Contemporary Translation Theories', London and New York: Routledge.

Hans Robert Jauss, (1982), 'TOWARD ANAESTHETIC OF RECEPTION', Trans. Timothy Bahti. Minneapolis: University of Minnesota Press, 1982.

Hermans, T. (1999). 'Translation and normativity'. In C. Schäffner (Ed.) Translation and norms (pp. 50-71). Philadelphia: Multilingual Matters.

"hermeneutics." YourDictionary, n.d. Web. 5 October 2015 .<http://www.yourdictionary.com/hermeneutics>.

"hermeneutics." OxfordDictionaries, n.d. Web. $\quad 13$ August 2017<https://en.oxforddictionaries.com/definition/hermeneutic>

Hershey MArgorie R., 'Just the Facts 101- Party Politics in America' (2017), <https://books.google.com.eg/books?isbn=1497025087>

"International Journal of Humanities and Social Science", (2013), <www. ijhssnet. com/ journals/Vol_3_No_18_October_2013/6.pdf>

Miller Dave, (2012), 'Stuart Hall \& Reception theory', published on 9 July $2012<$ http://davemiller.org/davemiller/stuart-hall-reception-theory>

Newmark, P. (1982) 'Approaches to Translation', Oxford and NewYork: Bergman. 
Newcombe \& Uttal (2006); Chapman \& Routledge (2005:268-71): <https://en.wikipedia.org/wiki/Benjamin_Lee_Whorf\#cite_note-Heynick_1983-2〉

Nida, E.A, C.R. Taber, (1985) 'The Theory and Practice of Translation', U.B.C,.

Palmer ,F.R. (1981) 'Semantics', (Cambridge : Cambridge University Press).

Robinson James M, (2007), 'Theology as Translation', <http://theologytoday.ptsem.edu/jan1964/v20-4-article6.htm>

Theo, Hermans, (2014), 'Manipulation of literature: studies in literary translation.' Abingdon; New York: Rutledge 